\title{
Evaluation of strip-tillage and conventional tillage in maize production
}

\author{
Sándor Ferencsik - Tamás Rátonyi \\ University of Debrecen Faculty of Agricultural and Food Sciences and Environmental Management \\ Institute of Land Utilisation, Technology and Regional Development, Debrecen \\ ferencsik@agr.unideb.hu
}

\section{SUMMARY}

Tillage changes soil properties and the way how the environment affects those properties. Soil properties and environment determine the rate of water movement in liquid and gaseous form into and out of soil. Based on the experimental database of the Institute of Land Utilisation, Regional Development and Technology of the University of Debrecen, Faculty of Agricultural and Food Sciences and Environmental Management and the KITE PLC, various cultivation systems were examined with maize (Zea mays L.) as indicator plant in Jász-Nagykun-Szolnok county. The sample area can be found in the outskirts of Kenderes on a meadow chernozem soil. On the examined plot, strip-tillage, subsoiling and moldboard ploughing were performed, each on 4.5 ha, respectively. The purpose of the present study is to compare these cultivation systems according to the soil-and maize kernel moisture content and to the yield based on the years of 2012 and 2013.

Keywords: soil tillage, moisture, strip-tillage, moldboard ploughing, subsoiling, maize yield

\section{ÖSSZEFOGLALÁS}

A talajmüvelés megváltoztatja a talajtulajdonságokat, valamint befolyásolja a környezeti hatások érvényesülését. A talajjellemzök és a környezet együttesen határozzák meg a talaj vizforgalmát. A Debreceni Egyetem Földhasznositási, Müszaki és Területfejlesztési Intézetének, valamint a KITE Zrt. kutatási adatbázisának alapján különbözö talajmüvelési rendszereket hasonlítottunk össze kukorica (Zea mays L.) jelzőnövény segitségével. A kisérleti terület Jász-Nagykun-Szolnok megyében, Kenderes külterületén található réti csernozjom talajon. A vizsgált táblán mintegy 4,5 ha öszi sávos alapmüveléssel, 4,5 ha középmély-lazítással, valamint 4,5 ha öszi szántással került megmüvelésre. Tanulmányunk célja a különbözö talajmüvelési rendszerek összehasonlítása talaj-és szemnedvesség-tartalom, valamint hozamok alapján a 2012-es és 2013-as vizsgálati éveket tekintve.

Kulcsszavak: talajmüvelés, nedvesség, sávos müvelés, öszi szántás, lazitás, kukorica hozam

\section{INTRODUCTION}

Maize yields were very variable in Hungary in the last few years. The year-to-year variability of maize yields is primarily due to the effects of the growingseason weather. The most obvious weather influences on maize yields is precipitation during the growing season (Hollinger and Changnon, 1993). In Hungary, the annual average temperature increase was $0.68{ }^{\circ} \mathrm{C}$, while the annual average of precipitation decrease was $83 \mathrm{~mm}$ during the last century (Jolánkai et al., 2004).

Tillage influences maize growth and yields by changing soil structure and moisture removal patterns over the growing season. Soil structure and moisture removal changes depend on soil properties, types of tillage and climatic conditions (Gruber et al., 2011).

According to the terminology of the American Society of Agricultural Engineers, conventional tillage is a form of tillage, in which the operations traditionally performed in preparing a seedbed for a given crop and grown in a given geographical area, while strip-tillage is a system in which $30 \%$ or less of the soil surface (bands in the row) is tilled (ASAE Standards, 2006). It clears the crop residues in a narrow zone of soil and loosens subsoil layers prior to planting. This tillage zone in typically 20 to $30 \mathrm{~cm}$ wide and 25 to $35 \mathrm{~cm}$ deep. The residue-covered area between these strips is left undisturbed.

Inversion tillage by moldboard ploughing is a traditional method of tillage world-wide and in Hungary, too. In the last few decades, disadvantages of soil inversion have become more evident particularly in semi-arid or continental climates. In a long-term soil tillage experiment Gyuricza et al. (2004) obtained higher soil moisture values in the reduced tillage systems compared to moldboard ploughing, however, there were significant differences only in the upper $(0-10 \mathrm{~cm})$ cultivated layer.

In respect of the yields between various cultivation systems the results are contradictory. Wysocki (1986), Lamm and Aiken (2007) reported crop yields were lower with strip-tillage than conventional tillage. Recent studies (Vyn and Raimbault, 1993; Opuku et al., 1997) found out that there are no significant differences between strip-tillage and moldboard ploughing yields, while (Ferencsik, 2013; Sulyok et al., 2013) reported that strip-tillage increased yield compared to conventional tillage.

The objective of this study is to evaluate the effects of the various cultivation systems on soil moisture content, on maize kernel moisture content and on yields.

\section{MATERIALS AND METHODS}

Based on the experimental database of the Institute of Land Utilisation, Regional Development and Technology of the University of Debrecen, Centre for Agricultural and Applied Economic Sciences and the KITE PLC, various cultivation systems were examined with maize (Zea mays L.) as indicator plant in JászNagykun-Szolnok country. The sample area can be found in the outskirts of Kenderes (N 47 14 '37'; E 
$20^{\circ} 38^{\prime} 01$ ') on meadow a chernozem soil. The monthly average precipitation and temperature from primary tillage until harvesting are shown in Figure 1-2. The precipitation was $333 \mathrm{~mm}$ in 2011-2012, while it was $683 \mathrm{~mm}$ in 2012-2013.

Figure 1-2: Precipitation and average temperature from primary tillage until harvesting in Kenderes in 2011-2012 and 2012-2013
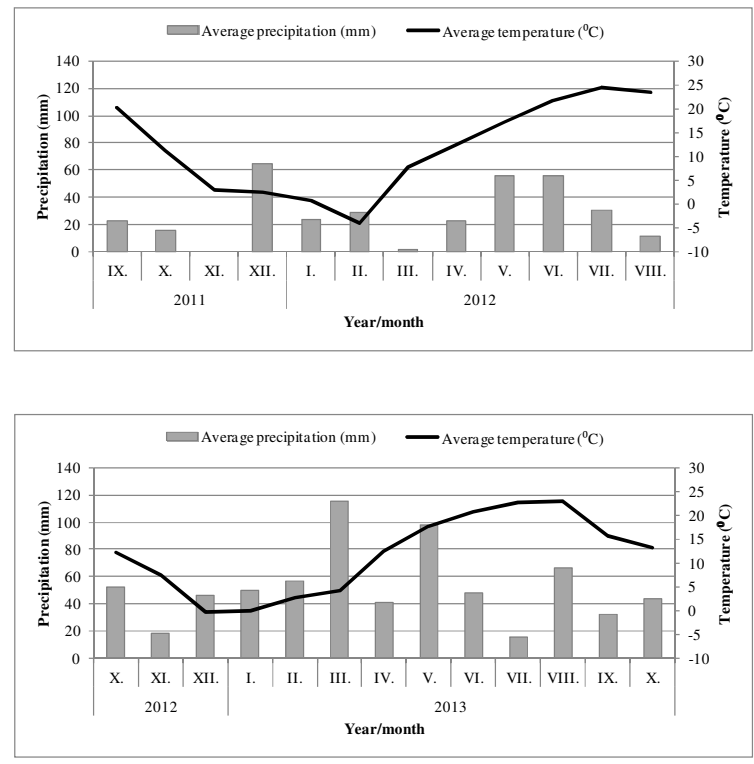

Source: KITE PLC database (2013)
On the examined plot, strip-tillage, subsoiling and moldboard ploughing were performed, each on $4.5 \mathrm{ha}$, respectively. The technology of the examined cultivation systems is shown in Table 1.

Moisture content of maize was quantified with Infratec 1241 Grain Analyzer. Infratec 1241 is a whole grain analyser which uses near-infrared transmittance technology to test multiple parameters (moisture, protein, oil, starch etc.) of grain and oilseed commodities.

Undisturbed soil samples were taken from each treatment from the upper $(0-10 \mathrm{~cm})$ cultivated layer before sowing in 2012 to determine the soil moisture content. In 2013 the soil moisture measurements were performed with a Field Scout TDR 300 soil moisture meter. Electronics in the TDR 300 generate and sense the return of a high energy signal that travels down and back, through the soil, along the waveguide composed of the two replaceable, stainless steel rods. After using a calibration curve to determine the soil moisture content in the $0-20 \mathrm{~cm}$ layer, the meter's period readings were related to volumetric water content. Determination of the minimum number of measurements for given error of estimation was based on Sváb (1981) method:

$$
\mathrm{n}=\frac{\mathrm{t}_{\mathrm{p} \%}^{2} \times \mathrm{s}^{2}}{\mathrm{~h}^{2}}
$$

where:

$\mathrm{n}=$ minimum number of measurements

$\mathrm{t}_{\mathrm{p} \%}=$ critical value of $\mathrm{t}$-test for given probability and degrees of freedom

$\mathrm{s}=$ standard deviation

$\mathrm{h}=$ error of estimation

Table 1.

Description of the examined cultivation systems

\begin{tabular}{lccc}
\hline & Strip-tillage & Subsoiling & Moldboard ploughing \\
\hline Stubble stripping & Disk & Disk & Disk \\
Stubble cultivation & Chemical & Chemical & Chemical
\end{tabular}

Fertilisation (autumn)

Primary tillage

Orthman 1tRIPr (primary tillage

and fertilisation at the same time)
Axis fertiliser spreader

Gaspardo Artiglio (7 shank)

Mulch finisher
Axis fertiliser spreader

Kühne moldboard plough (5 bottom)

Mulch finisher

Secondary tillage

JD 1750 + row cleaner + fertilisation JD 1750 + row cleaner + fertilisation

JD $1750+$ row cleaner + fertilisation

Feeding

\section{$\mathrm{JD} 1750+$}

\begin{tabular}{lc} 
Weed control & JD 4730 (chemical) \\
Fertilisation & Injection \\
Harvesting & JD W540 \\
\hline
\end{tabular}

Source: KITE PLC database (2013)

Maize grain yields were adjusted to $145 \mathrm{~g} \mathrm{~kg}^{-1}$ moisture.

Data were analyzed using the R statistical software (R Core Team, 2012) by one way ANOVA and Duncan's multiple-range test with the package agrocolae (Mendiburu, 2013), when treatment effects were significant. Statistical significance was evaluated at $\alpha=0.1$. In the figures columns marked by the same letter have no significant difference according to Duncan's multiple-range test.
All of the tables and figures were created with Microsoft Excel 2007.

\section{RESULTS}

Before sowing in 2012, the highest soil moisture content was observed in the strip-tillage treatment, in the inter-rows $\left(22.97 \mathrm{~V} \mathrm{~V}^{-1} \%\right)$ and the lowest was measured in moldboard ploughing $\left(18.24 \mathrm{~V} \mathrm{~V}^{-1} \%\right)$. 
There is no significant difference between the various cultivation systems based on the analysis of variance, except the strip-tillage inter-rows. The undisturbed soil profile had significantly higher moisture content (Figure 3).

Figure 3: Soil core sampling results in relation to each treatment (Kenderes, 2012)

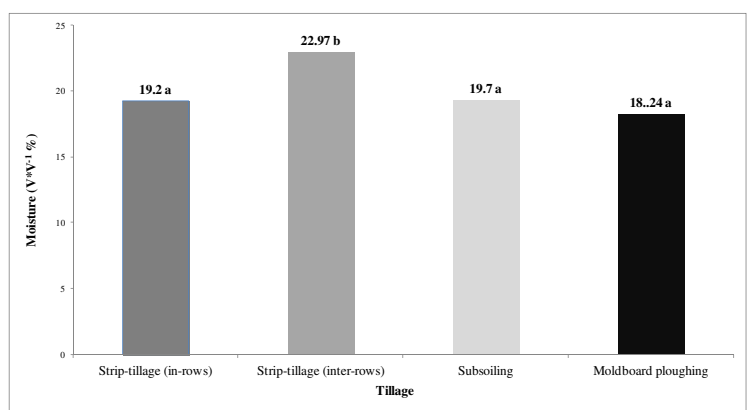

Based on the determination of the minimum number of measurements, there were taken 50 measurements with TDR 300 soil moisture meter in each treatment before sowing in 2013. Figure 4 shows the results in relation to each treatment. Tillage effects on soil moisture content were significant in the upper $(0-20 \mathrm{~cm})$ cultivated layer. The highest soil moisture content was observed in the strip-tillage inter-rows. Between the cultivated striptillage in-rows and subsoiling there was no significant difference, while in the case of moldboard ploughing the lowest soil moisture content was measured, which was almost $10 \%$ lower than in the case of the inter-rows of the strip-tillage treatment.

Figure 4: TDR 300 measuring results $(0-20 \mathrm{~cm})$ in relation to each treatment before sowing (Kenderes, 2013)

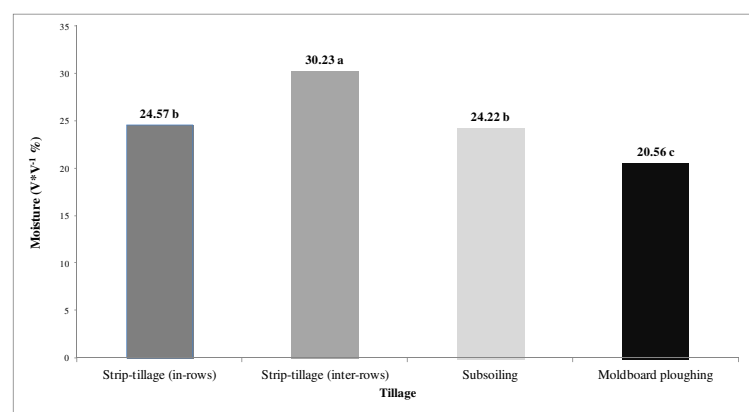

2012 was an extremely droughty year. The maize yields were significant higher in the case of strip-tillage and subsoiling treatment, then in the moldboard ploughing (Figure 5) and the tendency of the maize kernel moisture content results were similar. The maize moisture content was significantly higher in the case of strip-tillage and subsoiling treatment than in the moldboard ploughing (Figure 6). There was no significant difference between strip-tillage and subsoiling treatment according to the maize yields and moisture content of maize kernel either.

There was no significant difference between tillage systems according to the maize yields (Figure 7) based on the analysis of variance in 2013, but there were significant differences between all cultivation systems according to the maize kernel moisture content. The highest kernel moisture content was in the strip-tillage treatment, while the lowest was measured in the moldboard ploughing. The subsoiling technology has $1.6 \%$ lower maize moisture content than strip-tillage and $4 \%$ higher than moldboard ploughing (Figure 8).

Figure 5: Average maize yield in various cultivation systems (Kenderes, 2012)

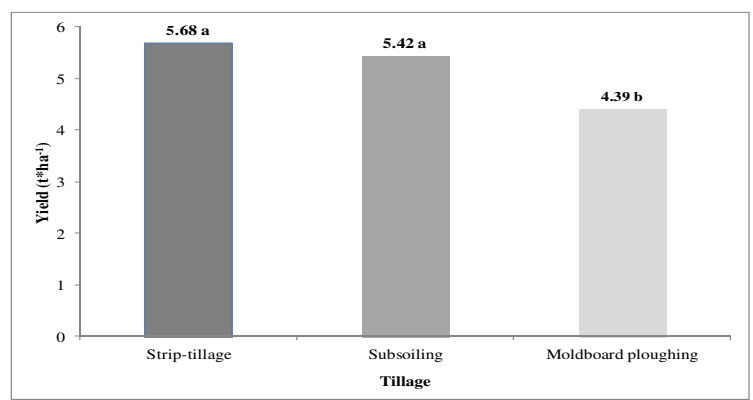

Figure 6: Moisture content of maize kernel in various cultivation systems (Kenderes, 2012)

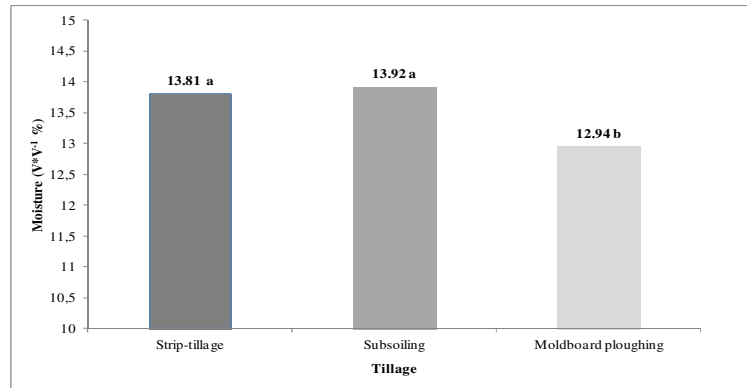

Figure 7: Average maize yield in various cultivation systems (Kenderes, 2013)

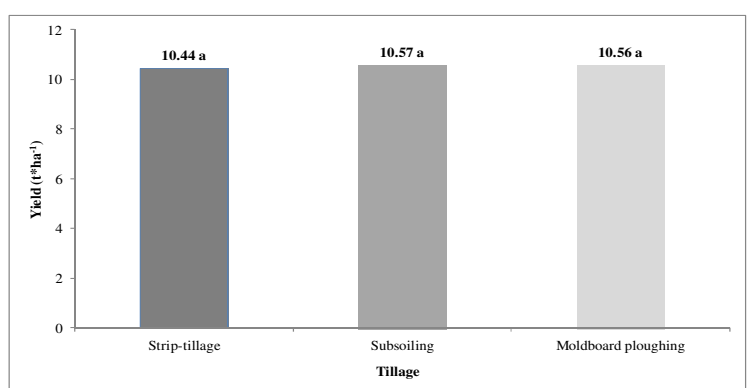

Figure 8: Moisture content of maize kernel in various cultivation systems (Kenderes, 2013)

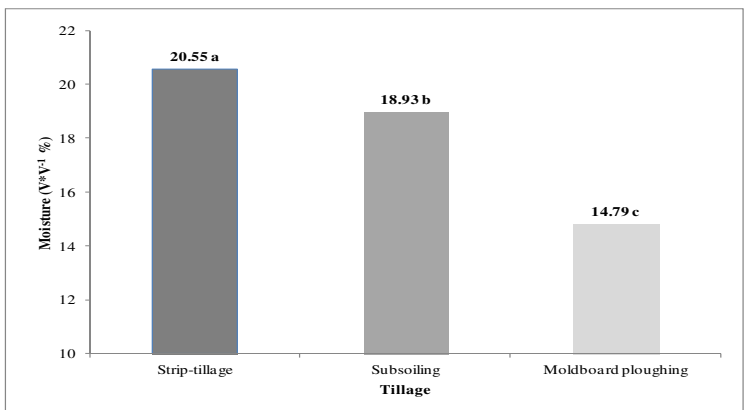




\section{CONCLUSIONS}

The effects of primary tillage on maize kernel moisture content were significant in both years. The maize kernel moisture content was significantly higher in the strip-tillage and subsoiling technology compared to moldboard ploughing. The moisture content of maize has to be taken into consideration in the cost-benefit analysis.

Our findings show that the soil moisture content was affected by the primary tillage in the cultivated layer. On the basis of undisturbed soil samples (which were taken in 2012) we could not confirm differences except for the undisturbed strip-tillage inter-rows between tillage systems in the upper cultivated layer according to the soil moisture content. The soil moisture content was higher in the strip-tillage and subsoiling technology compared to moldboard ploughing in 2013.
The results of this study show that we could not confirm relationship between soil moisture content before sowing and maize yields. The maize yields were higher in the reduced (strip-tillage and subsoiling) systems than in conventional (moldboard ploughing) tillage by droughty weather conditions in 2012. There was no significant difference between the treatmens according to the maize yields in 2013 .

In general, our findings show, that strip-tillage and subsoiling can be alternative tillage systems beside moldboard ploughing on meadow chernozem soils in Hungary.

\section{ACKNOWLEDGEMENTS}

The research was supported by KITE PLC and Kenderes 2006 Ltd.. We would like to thank dr. Dénes Sulyok for helping our research work.

\section{REFERENCES}

ASAE Standards (2004): Terminology and Definitions for Soil Tillage and Soil-Tool Relationships. Ep. 291. 2. St. Joseph. MI. USA

Ferencsik S. (2013): Különböző talajművelési rendszerek agronómiai és ökonómiai értékelése réti talajon. Agrártudományi Közlemények. 51: 103-106

Gruber, S.-Möring, J.-Claupein, W. (2011): On the way towards conservation tillage-soil moisture and mineral nitrogen in a longterm field experiment in Germany. Soil \& Tillage Research. 115116: 80-87.

Gyuricza Cs.-Liebhard P.-Rosner J. (2004): Talajökológiai tényezők vizsgálata talajművelési tartamkísérletekben [In: Birkás M.Gyuricza Cs. (szerk.) Talajhasználat. Müveléshatás. Talajnedvesség.] SZIE. Gödöllő.

Hollinger, S. E.-Changnon, S. A. (1994): Response of Corn and Soybean Yields to Precipitation Augmentation and Implications for Weather Modification in Illinois. Champaign. Illinois. 4.

Jolánkai M.-Láng I.-Csete L. (2004): Hatások és alkalmazkodás. Természet Világa. 135: 16-18.

Lamm, F.-Aiken, R. (2007): Tillage and irrigation capacity effects on corn production. ASAE Paper 072283. ASAE. St. Joseph. MI. USA
Mendiburu, F. (2013): Agricolae: Statistical Procedures for Agricultural Research. R package version 1.1-4. http://CRAN.R-project.org/ package $=$ agricolae

Opoku, G.-Vyn, T. J.-Swanton, C. J. (1997): Modified no-till systems for corn following wheat on clay soils. Agronomy Journal. 89: $549-556$.

R Core Team (2012): R: A language and environment for statistical computing. R Foundation for Statistical Computing. Vienna. Austria. http://www.R-project.org/.

Sulyok, D.-Ferencsik, S.-Rátonyi, T.-Huzsvai, L.-Nagy, J. (2013) Agronomical and agro-economic evaluation of maize production in various cultivation systems. Növénytermelés. Supplement. 62: $33-36$.

Sváb J. (1981): Biometriai módszerek a kutatásban. Mezőgazdasági Kiadó. Budapest. 50-51.

Vyn, T. J.-Raimbault, B. A. (1993): Long-term effect of five tillage systems on corn response and soil structure. Agron. J. 85: 1074 1079 .

Wysocki, D. (1986): A strip-till planting system for no-till fallow. PNW Conservation Tillage Handbook Series. System and Equipment. 3. Chapter 2. 